\title{
KOBIETA I KOBIECOŚĆ W OPARACH ULOTNEGO ŚWIATA (UKIYO), CZYLI NA POGRANICZU RZECZYWISTOŚCI I ARTYSTYCZNEJ ULUDY (NA PRZYKŁADZIE TEATRU KABUKI I DRZEWORYTU UKIYO-E)
}

\author{
ESTERA ŻEROMSKA ${ }^{1}$ \\ (Uniwersytet im. A. Mickiewicza w Poznaniu)
}

Słowa kluczowe: teatr kabuki, Okuni, aktor onnagata, drzeworyt japoński (ukiyo-e)

Key words: kabuki theatre, Okuni, onnagata actor, Japanese woodcut (ukiyo-e)

\begin{abstract}
Abstrakt: Estera Żeromska, KOBIETA I KOBIECOŚĆ W OPARACH ULOTNEGO ŚWIATA (UKIYO), CZYLI NA POGRANICZU RZECZYWISTOŚCI I ARTYSTYCZNEJ UŁUDY (NA PRZYKŁADZIE TEATRU KABUKI I DRZEWORYTU UKIYO-E). „PORÓWNANIA” 12, 2013, T. XII, s. 225-233. ISSN 1733-165X. U progu XVII wieku Japończycy znali jedynie teatr nō $(\mathrm{XIV} / \mathrm{XV})$ i integralnie $\mathrm{z}$ nim związaną, wystawianą na tej samej scenie $\mathrm{w}$ ramach tego samego przedstawienia farsę kyōgen (XIV/XV). Przyzwyczajeni też byli do tego, że w teatrze występowali wyłącznie mężczyźni. Kiedy zatem w 1603 roku, który wyznaczył początek trwającego do 1868 roku okresu Edo, w Kioto pojawiła się utalentowana tanecznie kapłanka ze świątyni w Izumo, Okuni (Izumo-no Okuni), nikt nie spodziewał się, że w bliskiej przyszłości występ ten okaże się zalążkiem kabuki - nowego gatunku teatralnego, który wraz z teatrem lalkowym (jōruri) błyskawicznie stanie się ulubioną rozrywką mieszkańców większości japońskich miast (zwłaszcza Kioto i Edo) oraz jednym z głównych symboli kultury mieszczańskiej. Rozkwitała ona wprawdzie na marginesie oficjalnego kręgu ascetycznej kultury samurajskiej, ale z tak dużą żywiołowością, że nawet surowe ograniczenia narzucane przez ówczesne władze wojskowe (bakufu) nie wpływały na nią hamująco. Kolejni sioguni nie byli w stanie odstraszyć mężczyzn od przekraczania bram dzielnic rozpusty, nie zdołali powstrzymać rozwoju kabuki czy drzeworytu (ukiyo-e), którego wybitnie utalentowani twórcy z upodobaniem utrwalali ulotne chwile (ukiyo) z życia urodziwych gejsz, sławnych aktorów i zwykłych ludzi. Artykuł jest poświęcony kobiecie i kobiecości w życiu i na scenie kabuki w Japonii okresu Edo.
\end{abstract}

\footnotetext{
${ }^{1}$ Correspondence Address: esu1@gazeta.pl
} 
Abstract: Estera Żeromska, WOMEN AND FEMINITY IN THE FLOATING WORLD (UKIYO): BETWEEN REALITY AND ARTISTIC VISION (BASED ON THE KABUKI THEATRE AND WOODBLOCK PRINTS UKIYO-E). "PORÓWNANIA" 12, 2013, Vol. XII, p. 225-233. ISSN $1733-165 X$. In the beginning of the $17^{\text {th }}$ century, the Japanese knew only the $n \bar{o}$ theatre $\left(14^{\text {th }}-15^{\text {th }} \mathrm{c}.\right)$, and integrally related to it, the kyogen farce $\left(14^{\text {th }}-15^{\text {th }} \mathrm{c}\right.$.), played on the same stage during the same performance. They were used to the fact that only men played in the theatre. When in 1603, which marks the beginning of the Edo period lasting until 1868, a rhythmically-gifted priestess from Izumo shrine, Okuni (Izumo-no Okuni), appeared in Kyoto, nobody suspected that in the near future her performance would give rise to kabuki - a new theatrical genre, which together with the puppet theatre (jöruri) would immediately become a favorite pastime of inhabitants of most of the Japanese cities (especially Edo and Kyoto), and one of the symbols of the urban culture. It flourished outside the official sphere of the ascetic samurai culture, but with such vivaciousness that even strict regulations imposed by the military government (bakufu) did not prevent its development. Consecutive shogun were not capable of stopping men from visiting the pleasure quarters, nor preventing the development of the kabuki and woodblock printing (ukiyo-e), whose outstanding creators portrayed with gusto the floating world (ukiyo) of beautiful geishas, famous actors and commoners. The article focuses on women and feminity in everyday life and in the kabuki theatre in Japan of the Edo period.

U progu XVII wieku Japończycy znali jedynie teatr $n \bar{o}(\mathrm{XIV} / \mathrm{XV})$ i integralnie $\mathrm{z}$ nim związaną, wystawianą na tej samej scenie $\mathrm{w}$ ramach tego samego przedstawienia farsę kyōgen (w. XIV/XV)2. Przyzwyczajeni też byli do tego, że $\mathrm{w}$ teatrze występowali wyłącznie mężczyźni. Kiedy zatem w roku 1603, który wyznaczył początek trwającego do roku 1868 okresu Edo (inaczej: Tokugawa), w Kioto pojawiła się utalentowana tanecznie kapłanka ze świątyni w Izumo, Okuni (Izumo-no Okuni), nikt nie spodziewał się, że jej pokaz taneczny nad brzegiem rzeki Kamo przejdzie do historii. Nikt bowiem nie przypuszczał, że w bliskiej przyszłości występ ten okaże się zalążkiem kabuki - nowego gatunku teatralnego, który wraz z teatrem lalkowym (jōruri) błyskawicznie stanie się ulubioną rozrywką mieszkańców większości japońskich miast (zwłaszcza Kioto i Edo) oraz jednym z głównych symboli kultury mieszczańskiej. Rozkwitała ona wprawdzie na marginesie oficjalnego kręgu ascetycznej kultury samurajskiej, ale z tak dużą żywiołowością, że nawet surowe ograniczenia narzucane przez ówczesne władze wojskowe (bakufu) nie wpływały na nią hamująco. Kolejni siogun ${ }^{3}$ nie byli bowiem w stanie odstraszyć mężczyzn od przekraczania bram dzielnic rozpusty, nie zdołali powstrzymać

2 Tradycyjny, trwający prawie cały dzień program przedstawienia teatru nō składa się z pięciu sztuk nō oraz czterech, wystawianych pomiędzy nimi, fars kyōgen. Po drugiej wojnie światowej programy spektakli są zwykle skracane (najczęściej do jednej lub dwóch sztuk nō).

3 W latach 1603-1867 w Japonii władzę sprawowali sioguni z rodu Tokugawa. Od tego nazwiska pochodzi druga nazwa okresu (okres Tokugawa) używana wymiennie z nazwą „okres Edo". 
rozwoju kabuki czy drzeworytu (ukiyo-e), którego wybitnie utalentowani twórcy $\mathrm{z}$ upodobaniem utrwalali ulotne chwile (ukiyo) z życia urodziwych gejsz, sławnych aktorów i zwykłych ludzi.

Dwoma głównymi ośrodkami kultury mieszczańskiej w okresie Edo był najpierw (w latach 1688-1704) rejon Kioto, gdzie rezydował cesarz oraz późniejsi władcy (w latach 1804-1829)4 miasto Edo (obecne Tokio), gdzie żył i tworzyli najwybitniejsi japońscy twórców drzeworytów (ukiyo-e), jak Katsushika Hokusai (1760-1849), Andō Hiroshige (1797-1858), Utagawa Kuniyoshi (1797-1861) czy Tōshūsai Sharaku (lata życia nieznane). Ponad miastem Edo, którego więcej niż połowę mieszkańców stanowili mężczyźni, wznosił się zamek sioguna (Edo-jō). Po jednej stronie tego zamku znajdowały się domy (przybyłych z całego kraju) książąt feudalnych (daimyō) zobligowanych przez sioguna do spędzania w stolicy sześciu miesięcy $\mathrm{w}$ roku. Po drugiej stronie zamku, usytuowanej na mniej atrakcyjnych nizinnych terenach, rozrastało się Shitamachi (Dolne Miasto) - prawdziwy raj dla niedocenianych przez władze kraju kupców i rzemieślników, dla stęsknionych za rodzinami książąt feudalnych, dla samurajów mieszkających w specjalnych, zamkniętych dla kobiet osiedlach, a także artystów, dla których na oficjalnej drabinie społecznej w ogóle nie było miejsca.

Książęta feudalni, podobnie jak bogaci kupcy czy zubożali samuraje poszukujący odskoczni od rutyny codzienności i często niekochanej (bo poślubionej z obowiązku wobec własnego rodu) żony - to główni bywalcy usytuowanych wzdłuż rzecznego nabrzeża herbaciarni, to klienci pospolitych prostytutek (yūzo), goście luksusowych kurtyzan, to widzowie teatru kabuki.

W Edo szczególnym powodzeniem cieszyła się Yoshiwara - dzielnica uciech usytuowana początkowo w centrum miasta, nieopodal słynnego mostu Nihonbashi, który był zarazem punktem granicznym Tōkaidō - owianego legendą, utrwalonego na drzeworytach głównego traktu handlowego między Edo a Kioto. Niepokojąca władze Japonii popularność Yoshiwary sprawiła, że to siedlisko rozwiązłości zostało przeniesione na przedmieście i nazwane Shin Yoshiwara (Nowa Yoshiwara). Nieoczekiwanie dzięki temu nastąpiło zbliżenie świata gejsz ze środowiskiem aktorów kabuki, z których wielu świadczyło usługi homoseksualne (nanshoku) w pobliskiej dzielnicy Saruwaka.

Do Yoshiwary z centrum Edo dopływało się łodzią nurtem Sumidy. Za zamykaną na noc bramą tej dzielnicy zanikały bariery społeczne, ponieważ na ten bacznie strzeżony, ogrodzony teren samuraje wchodzili bez mieczy i, podobnie jak pozostali przybysze, często odziani byli $\mathrm{w}$ uniwersalne, niewskazujące na przynależność klasową ubiory.

${ }^{4} \mathrm{~W}$ historii japońskiej kultury, w trwającym 268 lat okresie Edo wyróżnia się dwa podokresy: Genroku (1688-1704) - ze względu na szczytowy rozwój kultury mieszczańskiej w rejonie Kansai (Osaka, Kioto) oraz Bunka-bunsei (1804-1829) - ze względu na szczytowy rozwój kultury mieszczańskiej w rejonie Kantō (miasto Edo i okolice). 
Na tle jednolitego męskiego tłumu jedynie kurtyzany zwracały uwagę swymi wykwintymi strojami, wyrazistym makijażem, dystyngowanymi manierami. Mężczyźni, mimo zawrotnych kosztów, lgnęli do nich nie tylko po to, aby zaspokoić potrzeby ciała, ale niekiedy jedynie dla przyjemności konwersacji z tymi wszechstronnie wykształconymi kobietami powołanymi do uprzyjemniania im czasu śpiewem, grą na instrumencie czy tańcem.

Również budynki teatralne kabuki początkowo były usytuowane w centrum Edo, nieopodal pierwotnej Yoshiwary. W połowie XVII wieku w stolicy działały już trzy duże zespoły kabuki (edo-sanza), ale po pożarze miasta w roku 1841 zostały one przeniesione na przedmieście - również w pobliże Nowej Yoshiwary, a także wspomnianej Saruwaki i słynnej świątyni buddyjskiej Sensō-ji w dzielnicy Asakusa, gdzie rezydowało wiele gejsz.

Do teatrów kabuki najchętniej przychodzili mieszczanie, zwłaszcza kobiety. Ich ulubionymi sztukami były te, z których bohaterami mogli się utożsamiać, a zwłaszcza utwory o konieczności dokonywania wyboru między uczuciem i obowiązkiem (giri-ninjō). Wielkie emocje budziły historie miłosne kończące się samobójstwem popełnianym przez oboje nieszczęśliwych, niemających szans na wspólną przyszłość, kochanków (shinjū-mono).

Popularność kabuki sprawiała, że aktorzy tego teatru, choć dyskryminowani przez władze kraju, żyli w aureoli sławy i byli powszechnie znani. Szczególny podziw wzbudzali odtwórcy ról kobiecych.

Pojawienie się w kabuki żeńskiego emploi (onna-gata) było efektem restrykcji dwukrotnie wprowadzonych przez sioguna - w 1629 i 1652 roku. Za pierwszym razem (1629) zakazem całkowitego występowania na scenie zostały objęte kobiety, ponieważ ich swobodne zachowanie prowokowało podziwiających je) mężczyzn do przekraczania granic przyzwoitości. Zastrzeżenia budził między innymi nenbutsu-odori, czyli taniec o buddyjskim rodowodzie ku czci Buddy Amidy - popisowy numer Okuni, która nacechowała go obrazoburczym erotyzmem podobnie jak prezentowane przez siebie liczne scenki $\mathrm{z}$ hulaszczego życia $\mathrm{w}$ dzielnicach uciech. Władzom nie podobało się również to, że w założonym przez Okuni kobiecym zespole (onna-kabuki - kobiece kabuki) oraz w licznych naśladujących go (wyłącznie żeńskich) grupach kobiety odgrywały role męskie 5 .

Za drugim razem (1652) zakaz sioguna dotyczył młodych chłopców (wakashū), którzy przejęli artystyczną spuściznę po Okuni. Ich wdzięk i uroda często działała zachęcająco na widzów o skłonnościach homoseksualnych ${ }^{6}$.

Dlatego od połowy XVII wieku na scenie kabuki, zgodnie z wcześniejszą japońską tradycją teatralną (nō, kyōgen), zaczęli się pojawiać wyłącznie mężczyźni i od-

\footnotetext{
${ }^{5}$ Za czasów Okuni (do 1629 roku) kabuki określano terminem onna-kabuki (kobiece kabuki), a w okresie 1629-1652 - wykashū-kabuki (kabuki młodych mężczyzn).

${ }^{6} \mathrm{Na}$ temat praktyk homoseksualnych w okresie Edo zob.: M. Newelska, Piękni, młodzi, kosztowni. Męskie praktyki homoseksualne w Japonii okresu Edo (1600-1868). Warszawa, 2011, s. 123-129.
} 
grywać role męskie i żeńskie7. Aktorzy specjalizujący się w rolach kobiecych (onnagata) do dziś zachwycają, zarówno jako zwykłe, skromne mieszczki, jak również jako najwyższej rangi kurtyzany, z elegancją poruszające się $\mathrm{w}$ ekscentrycznych strojach i fryzurach. Perfekcja warsztatu aktorskiego sprawiała, że w oczach widza stopniowo zacierała się granica między iluzją sceny a życiem i że odtwórcy żeńskich postaci stawali się obiektem szczególnego zainteresowania.

Prezentowane na scenie kabuki bohaterki szybko stały się uosobieniem męskiej wizji ideału kobiecości. Również współcześni odtwórcy onna-gata kreują stylizowane piękno, poruszając się i mówiąc $\mathrm{w}$ taki sposób, że widz całkowicie ulega magii ich gry, a iluzję postrzega jak prawdę. Aktorzy onna-gata od dziecka uczą się mistrzowskich umiejętności, niekiedy zatracając świadomość granicy między rzeczywistością i teatralną iluzją. Emanują doskonale delikatnym wdziękiem i naturalną skromnością sposobu bycia.

Twórcą podstaw techniki gry stosowanej w przypadku ról onna-gata i ich znakomitym wykonawcą był Yoshizawa Ayame I (inaczej: Yoshizawa Kikunojō, Yoshizawa Gonshichi; 1673-1729), który także w życiu prywatnym starał się zachowywać jak kobieta. Surowe zalecenia Yoshizawy upowszechniły się w świecie kabuki, mimo że nie brakowało aktorów sprzeciwiających się stosowania się, na co dzień, do jego nakazu kamuflowania wszelkich atrybutów męskości.

Współczesny aktor onna-gata znów może się czuć mężczyzną. Stale jednak chętnie korzysta ze wskazówek Yoshizawy, które dotyczą tajników techniki gry.

Innym wybitnym odtwórcą ról kobiet był Segawa Kikunojō (1693?-1749). Powstałą po jego śmierci lukę wypełnili dwaj równie utalentowani następcy - Nakamura Tomijūrō I (1719-1786) i Iwai Hanshirō (inaczej: Bandō Mitsugorō; 17451782). Do grona onna-gata, którzy przeszli do historii, należą ponadto: Nakamura Utaemon I (1714-1791), Onoe Kikugorō I (1717-1783), Nakamura Utaemon III (1778-1838), Nakamura Jakuemon I (1806-1871), Kataoka Hidetarō II (ur. 1941), Bandō Tamasaburō V (ur. 1950), Onoe Kikunosuke (ur. 1977) i wielu innych.

W przeszłości, jak w komedii dell'arte, aktorzy kabuki przypisani byli do jednego emploi (żeńskiego lub męskiego). Taka praktyka zasadniczo utrzymuje się do dziś, choć zdarza się, że niekiedy specjalista od ról męskich (tachiyaku) wciela się w kobietę lub przeciwnie.

W okresie Edo podziw dla aktorów kabuki, zwłaszcza kult onna-gata, był powodem, dla którego wielu wielbicieli kupowało drzeworytnicze wizerunki swych

\footnotetext{
${ }^{7}$ Na temat onna-gata por.: E. Żeromska, Japoński teatr klasyczny: korzenie i metamorfozy. T. 2: kabuki, bunraku. Warszawa, 2010, s. 99-104.

${ }^{8}$ Konieczność prowadzenia przez aktorów onna-gata proponowanego przez Yoshizawę zniewieściałego stylu życia kwestionuje na przykład wybitny specjalista od łagodnego stylu wagoto, Tōjūrō w Yakusha-rongo (1776). Zob. T. Kawatake, Bunraku and kabuki, w: A History of Japanese Theatre. T. 2. Kokusai Bunka Shinkokai (Japan Cultural Society), Yokohama 1971, s. 64.
} 
faworytów. W taki sam sposób pocieszali się niezbyt zamożni widzowie, niemogący pozwolić sobie zbyt często na bilet do teatru lub na korzystanie ze świadczonych przez niektórych aktorów kabuki bardzo kosztownych usług o charakterze homoseksualnym. Wielkie zapotrzebowanie na portrety mężczyzn, pięknych kobiet oraz aktorów kabuki - zwłaszcza onna-gata - sprzyjały rozwojowi drzeworytu (ukiyo-e), na którym - jak na dzisiejszej fotografii - utrwalano ulotne chwile (ukiyo) również z życia zwykłych ówczesnych mieszczan.

Na delikatnych, niewielkiej wielkości planszach spotykają się zatem mieszkanki Yoshiwary, mieszkańcy dzielnicy Saruwaka i aktorzy kabuki. Mistrzowie ukiyo-e, jak Torii Kiyonaga (1752-1815), Isoda Koryūsai (lata życia nieznane; tworzył w latach 1760-1780), Kitagawa Utamaro (1754-1806), Utagawa Kuniyoshi czy Suzuki Harunobu (1725?-1770) stworzyli bogatą galerię postaci kobiecych o mniejszej lub większej sławie. Każdy z tych artystów miał własny sposób podpatrywania rzeczywistości i niepowtarzalny styl. Piękne kurtyzany z ich rycin znane są dziś na całym świecie, a nasza wiedza o aktorach i teatrze kabuki byłaby na pewno o wiele uboższa bez tej malowniczej spuścizny.

Artyści należący do Szkoły Torii (Torii-ha), którą założył Torii Kiyonaga, najchętniej portretowali aktorów w scenicznym przebraniu, zwłaszcza odtwórców męskich ról wykonywanych w szortskim, dynamicznym stylu aragoto.

Przedstawiciele Szkoły Katsukawa (Katsukawa-ha), powołanej przez Katsukawę Shunshō (1726-1792), interesowali się zarówno scenicznymi wcieleniami aktorów, jak i ich życiem pozascenicznym. Duży obiektywizm i realizm przedstawień postaci na planszach przyczyniały się do ogromnego zapotrzebowania na prace artystów należących do tej szkoły - zwłaszcza w ostatnich trzech dekadach XVIII wieku, kiedy kabuki znajdowało się w szczytowej fazie rozwoju.

Żaden jednak portrecista aktorów nie był w stanie przebić sławą tajemniczego Tōshūsaia Sharaku - twórcy o nieznanych latach życia i o niepotwierdzonej tożsamości. Jego oryginalny styl można bez trudu rozpoznać po „brutalnym” realizmie, dzięki któremu - w przeciwieństwie do wielu innych twórców - zdołał odzwierciedlić różne postaci (twarze) aktorów (w tym wielu odtwórców ról męskich).

Sharaku pozostawił po sobie sto pięćdziesiąt dziewięć plansz, które wykonał w ciągu niespełna roku (przełomie 1794/1795). Z niespotykanym u innych twórców ukiyo-e realizmem utrwalił na nich niewyidealizowane popiersia aktorów kabuki. Dzieła Sharaku są jedynym świadectwem istnienia tego artysty zamykającego ważny okres $\mathrm{w}$ historii ukiyo-e, a zarazem okres świetności portretowego drzeworytu w Japonii.

Do kryzysu w rozwoju drzeworytu przyczynili się władcy Japonii, którzy wprowadzili surową cenzurę tematyczną, ponieważ główną winą za postępujące rozprzężenie moralne społeczeństwa obarczali i znanych z rozwiązłości aktorów, i twórców drzeworytów, uwieczniających równie chętnie urodę artystów, jak i wdzięki luksusowych kurtyzan czy pospolitych prostytutek (yüjo). W tym okresie ograniczonej wolności artyści z konieczności zaczęli podejmować neutralne tematy. 
Nastała wówczas era wielkich pejzażystów, takich jak Katsushika Hokusai i Utagawa Hiroshige, a zarazem era miłośników grozy, jak Utagawa Kuniyoshi, który wbrew oficjalnym restrykcjom podejmował również tematy teatralne. Nie stronił on ani od utrwalania pracownic herbaciarni czy piękności z Yoshiwary, ani od portretowania sylwetek sławnych aktorów w kobiecym kostiumie (onna-gata).

Jednym z ulubionych tematów podejmowanych przez twórców drzeworytów (ukiyo-e) był główny wątek ze sztuk poświęconych młodej kobiecie obsesyjnie zakochanej bez wzajemności w pewnym kapłanie buddyjskim ze świątyni Dōjōji w Kioto. Według jednej z licznych wersji tej historii mnich chowa się we wnętrzu dzwonu, ale kiedy dziewczyna odkrywa prawdę, przemienia się w węża, oplata swoim ciałem dzwon, który pod wpływem ciepła topnieje, co powoduje śmierć nieszczęsnego mężczyzny.

Według innej wersji po pewnym czasie zakochana kobieta dowiaduje się czasie, że mnisi ze świątyni Dōjōji, do której należał jej ukochany, odbudowali dzwon i przygotowują się do uroczystości rytualnego poświącenia go. Wiedząc, że teren świątyni został otoczony i wprowadzono zakaz wstępu dla kobiet, dziewczyna ucieka się do fortelu - przebiera się za tancerkę (shirabyōshi) i zostaje dopuszczona do udziału w uroczystości. Popisuje się przed mnichami swymi tanecznymi umiejętnościami, ale w chwili, gdy kapłani zorientowali się, że padli ofiarą podstępu, kobieta ujawnia swą demoniczną naturę i wskakuje na dzwon.

$*$

W każdym klasycznym gatunku japońskiego teatru dramatycznego (nō, kyōgen, kabuki) w role kobiet wcielają się mężczyźni, którzy odpowiedni efekt, efekt kobiecości, osiągają środkami właściwymi dla danego gatunku. Reprezentujący je aktorzy (Kanze Tetsunojō IX - protagonista shite, nō; Nomura Manzō IX - deuteragonista ado, kyōgen; Kataoka Hidetarō - onna-gata, kabuki), zapytani przeze mnie o to, jak być kobietą, zdają się wprawdzie opowiadać różne historie, ale niewątpliwie wspólna jest im pełna pokora wobec przeszłości, a także odpowiedzialność za teraźniejszość i przyszłość klasycznego teatru japońskiego, na którego scenie pewnego dnia być może znów kobieta zagra kobietę.

\section{KANZE TETSUNOJŌ}

„Pewne role, jak starca okina, zawsze były niedostępne dla kobiet, które do nauki nō zaczęły być stopniowo dopuszczane od końca XIX wieku. Fakt ten zaakceptowano jednak po wielu dziesięcioleciach, a właściwie dopiero po drugiej wojnie światowej, kiedy [w Japonii] pojawiły się [pierwsze] zawodowe aktorki. [...]

Nō różni się od kabuki, którego założycielką była kapłanka Okuni z Izumo i gdzie początkowo występowały tylko kobiety. Nō jest sztuką wyrosłą z obrzędów 
poświęconych bóstwom. [Z powodu pewnych tabu] dopuszczano do nich wyłącznie mężczyzn. Przy okazji przeciwdziałano w ten sposób rozmaitym problemom wynikającym $\mathrm{z}$ nieustannego przebywania w jednym miejscu osób należących do obu płci. $[\ldots]$

[Jak wyrazić] kobiecość w nō [?]... Hmm... Bardzo trudno stać się kobiecym, skoro jest się tak potężnym jak ja mężczyzną (śmiech). Dlatego bez ciężkiej pracy nie można pokazywać się widzom. Niezależnie od tego czy gra się starą, czy młodą osobę, warunkiem osiągnięcia efektu kobiecości jest, poza odpowiednim sposobem poruszania się, bardzo świadomy sposób emisji głosu. To jest podstawa techniki. Mowę młodych kobiet cechuje kontrolowana potoczystość i łagodność, mowę staruszek, na których każdym słowie odciska się piętno przeszłości znacznie obniżony głos, spowolnione tempo przy jednoczesnym wzmocnieniu siły akcentowania. A zatem wyraźnie eksponuje się różnice wiekowe. Umożliwia to specjalna technika".

\section{NOMURA MANZŌ IX}

„[...] role dziecięce są przeznaczone dla dzieci, ale poza tym wiek nie ma większego znaczenia. Tę samą rolę może zagrać równie dobrze mój ojciec jak dziadek. Pod tym względem nie jest to teatr realistyczny. Zwłaszcza, jeśli występuje się $\mathrm{w}$ masce. Ale nawet bez maski niezbyt przystojny aktor wciela się $\mathrm{w}$ rolę pięknej młodej kobiety. Oczywiście lepiej, kiedy wiek aktora jest zbliżony do wieku postaci, którą odgrywa. Ale tak jak w tańcach ennen, bardzo wyczerpujące fizycznie role starszych osób, które wymagają poruszania się z pochylonym do przodu korpusem, łatwiej wykonać młodemu aktorowi. Oczywiście trzeba wtedy zakryć twarz maską i grać całym ciałem. To się często praktykuje, ale ze względu na stopień trudności takie role powierza się doświadczonym aktorom $\mathrm{w}$ średnim wieku, nie nastolatkom. W komedii efekt wynikający z różnicy wieku wykonawcy i przedstawianej przez niego postaci może się okazać interesujący, dlatego nie trzeba się tym zbytnio przejmować. $W$ tragedii to jest niedopuszczalne. Proszę sobie wyobrazić Szekspirowską Julię graną przez starą aktorkę. To byłaby farsa. [...]

[Kyōgen i kabuki] to są zupełnie inne, niemające z sobą nic wspólnego techniki gry. W kabuki aktor stara się za wszelką cenę być kobiecym, mówi bardzo wysokim głosem. W kyōgen też mężczyźni grają kobiety, ale wcale nie są kobiecy. Nie usiłują mówić wysokim głosem ani poruszać się zdecydowanie inaczej niż mężczyzna tylko dlatego, że grają kobietę. Nie stwarzają iluzji kobiecości. Występują w prostym kostiumie i w specjalnym nakryciu głowy, symbolizującym

\footnotetext{
${ }_{9}$ Pełny tekst tego wywiadu został zamieszczony w: E. Żeromska, Japoński teatr klasyczny: korzenie i metamorfozy. Tom 1: nō, kyōgen, op. cit., s. 371-382.
} 
długie włosy, a reszta wynika z tekstu sztuki. W kyōgen wiele bohaterek odznacza się różnymi przywarami. Niektóre z nich przez całą sztukę są bardzo krzykliwe i kłótliwe, ale ostatecznie pokornieją, godzą się z mężami, których przewyższają inteligencją. Wbrew pozorom, ulegając im, dają wyraz swej siły, miłości, mądrości. To typowy dla kyōgen sposób prezentowania kobiety" 10 .

\section{KATAOKA HIDETARŌ}

"Gram wiele ról - kobiet młodych, starych, demonicznych, zwykłych dziewczyn, księżniczek, przeistaczałem się w matki, żony, babcie. O tym, jak daną postać przedstawić, myślę dopiero wtedy, gdy zaczynam pracować nad rolą. Nie jestem kobietą, tylko ją gram. Zawsze staram się przeistoczyć $\mathrm{w}$ daną postać i zrobić to z jak największą naturalnością i wiarygodnością. Kiedy na przykład za wszelką cenę usiłuję pokazać dobre strony charakteru jakiejś uroczej osoby, efekt jest odwrotny, a przecież chodzi o to, żeby widz postrzegał moją bohaterkę jako dobrą. W kabuki nauczyłem się, że wcale nie trzeba pokazywać smutku, aby być smutnym i że nie trzeba się śmiać, aby być wesołym. Bo każda przesada wygląda na scenie sztucznie. Najważniejsza jest naturalność i przekonanie widza, że jest się wiarygodnym"11.

\section{BIBLIOGRAFIA}

Newelska Marta, Piękni, młodzi, kosztowni. Męskie praktyki homoseksualne w Japonii okresu Edo (16001868). Warszawa, Wydawnictwo Trio, 2011.

Pęgiel Urszula, Teatr i dramat Yashiro Seiichirō (maszynopis).

Romanowicz Beata, Utagawa Kuniyoshi. W świecie legend i fantazji. Kraków, Muzeum Narodowe w Krakowie, 2011.

Murase Miyeko, Sześć wieków malarstwa japońskiego. Od Sesshu do artystów wspótczesnych. Warszawa, Arkady, 1996.

Żeromska Estera, Japoński teatr klasyczny: korzenie i metamorfozy. Tom 2: kabuki, bunraku. Wydawnictwo Warszawa, Trio, 2010.

\footnotetext{
${ }^{10}$ Pełny tekst tego wywiadu został zamieszczony w: tamże, s. 455-468.

${ }_{11}$ Pełny tekst tego wywiadu został zamieszczony w: E. Żeromska, Japoński teatr klasyczny: korzenie i metamorfozy, tom 2: kabuki, bunraku, s. 174-181.
} 